\title{
Diketopyrrolopyrrole Based Organic Solar Cells Functionality: the Role of Orbital Energy and Crystallinity
}

Patricie Heinrichováa, Jan Pospíšila, Stanislav Stříteskýa, Martin Valaa, Martin Weitera, Petr Toman', David Raisb, Jiří Pflegerb, Martin Vondráčekc, Daniel Šimekc , Ladislav Feketec, Petra Horákovád, Lenka Dokládalovád, Lubomír Kubáčd and Irena Kratochvílová*c

a Materials Research Centre, Faculty of Chemistry, Brno University of Technology, Purkyňova 118, CZ-612 00 Brno, Czech Republic

bInstitute of Macromolecular Chemistry, Academy of Sciences of the Czech Republic, Heyrovský Sq. 2, 16206 Prague 6, Czech Republic

c Institute of Physics, Academy of Sciences of the Czech Republic, v.v.i, Na Slovance 2, CZ-182 21, Prague 8, Czech Republic

d Centrum Organické Chemie, Rybitví 296, CZ-533 54 Rybitví, Czech Republic

*Corresponding author: krat@fzu.cz

DPP synthesis
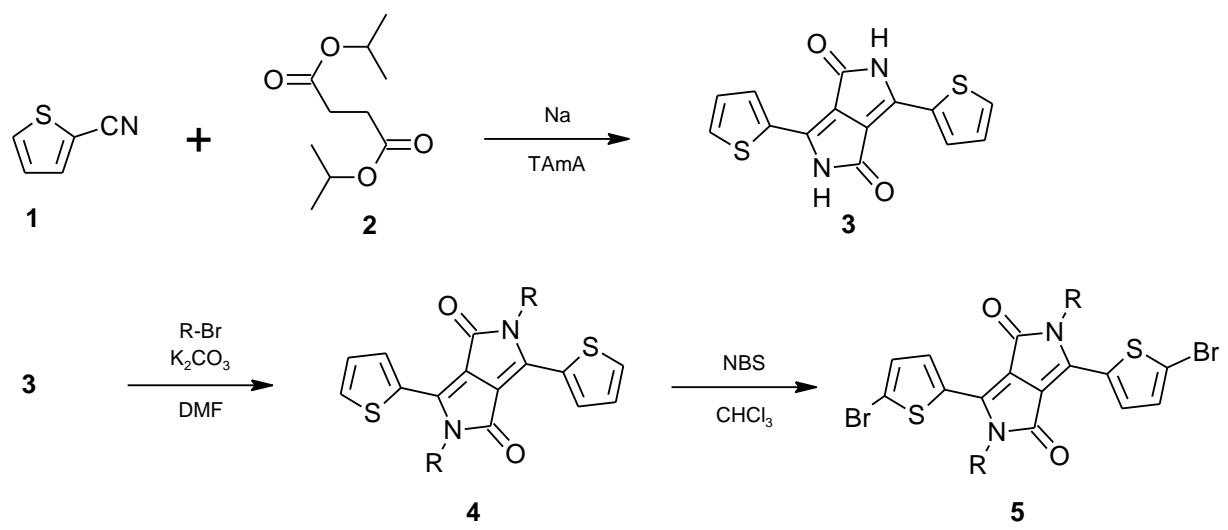

5

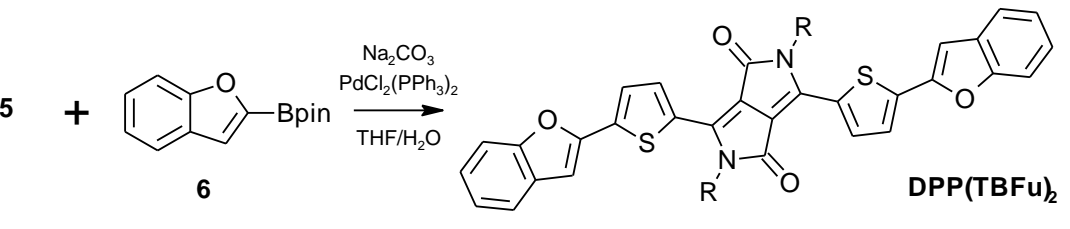

Scheme S1: DPP(TBFu $)_{2}$ 
2,5-bis(2-ethylhexyl)-3,6-bis(thiophen-2-yl)-1H,2H,4H,5H-pyrrolo[3,4-c]pyrrole-1,4-dione (4)

Under inert atmosphere, $3(15 \mathrm{~g}, 0.05 \mathrm{~mol})$ and 4 eq of $\mathrm{K}_{2} \mathrm{CO}_{3}(27.8 \mathrm{~g}, 0.2 \mathrm{~mol})$ were suspended in $250 \mathrm{ml}$ of dry DMF. The mixture was heated to $120{ }^{\circ} \mathrm{C}$. Then, were added succesively $4 \mathrm{eq}$ of 1-bromo-2-ethylhexane. The mixture was heated at $130{ }^{\circ} \mathrm{C}$ for $5 \mathrm{~h}$. After cooling to rt, $250 \mathrm{ml}$ of water was added. The suspension was filtered and washed with water. Pure product $4(9.7 \mathrm{~g}, 37 \%)$ was obtained through the poured with methanol, filtered and dried. ${ }^{1} \mathrm{H}$ NMR $\left(400 \mathrm{MHz}, \mathrm{CDCl}_{3}\right), \delta=8.89(\mathrm{dd}, J=3.88 \mathrm{~Hz}, 1.08 \mathrm{~Hz}, 2 \mathrm{H}), 7.63(\mathrm{dd}, J=5 \mathrm{~Hz}, 1,04 \mathrm{~Hz}$, $2 \mathrm{H}), 7.27(\mathrm{dd}, J=5.12 \mathrm{~Hz}, 3.96 \mathrm{~Hz}, 2 \mathrm{H}), 4.04-4.01(\mathrm{~m}, 4 \mathrm{H}), 1.86-1.85(\mathrm{~m}, 2 \mathrm{H}), 1.38-1.25(\mathrm{~m}, 16 \mathrm{H})$, 1.23-0.85 (m, 12H) ppm; ${ }^{13} \mathrm{C}$ NMR (400 MHz, $\left.\mathrm{CDCl}_{3}\right), \delta=161.71,140.39,135.25,129.79,128.39$, 109.33, 107.87, 45.81, 39.03, 30.15, 28.31, 23.49, 23.03, 13.99, 10.44 ppm. Compound 3 was prepared as reported in ${ }^{1}$.

3,6-bis(5-bromothiophen-2-yl)-2,5-bis(2-ethylhexyl)-1H,2H,4H,5H-pyrrolo[3,4-c]pyrrole-1,4dione (5)

$2.05 \mathrm{eq}$ of NBS $(3.47 \mathrm{~g}, 19.5 \mathrm{mmol})$ was added to $4(5 \mathrm{~g}, 9.5 \mathrm{mmol})$ in $100 \mathrm{ml}$ of chloroform. The mixture was stirred at $\mathrm{rt}$ for $3 \mathrm{~h}$. Then acetone $(2 \mathrm{ml})$ was added to quench the reaction. The mixture was succesively washed with water and brine. The organic solvent was removed by the reduced rotary evaporation. Pure product 5 (5.2 g, $80 \%)$ was obtained through the poured with methanol, filtered and dried. ${ }^{1} \mathrm{H}$ NMR $\left(400 \mathrm{MHz}, \mathrm{CDCl}_{3}\right), \delta=8.64(\mathrm{~d}, J=4.2 \mathrm{~Hz}$, $2 \mathrm{H}), 7.22(\mathrm{~d}, J=4.16 \mathrm{~Hz}, 2 \mathrm{H}), 3.95-3.91(\mathrm{~m}, 4 \mathrm{H}), 1.84(\mathrm{~m}, 2 \mathrm{H}), 1.37-1.24(\mathrm{~m}, 16 \mathrm{H}), 0.9(\mathrm{~m}, 12 \mathrm{H})$ ppm; ${ }^{13} \mathrm{C} \mathrm{NMR}\left(400 \mathrm{MHz}, \mathrm{CDCl}_{3}\right), \delta=161.38,139.38,135.38,131.45,131.13,119.01,107.97,45.98$, $39.07,30.14,28.29,23.52,23.01,14.00,10.51 \mathrm{ppm}$.

3,6-bis[5-(1-benzofuran-2-yl)thiophen-2-yl]-2,5-bis(2-ethylhexyl)-1H,2H,4H,5H-pyrrolo[3,4c]pyrrole-1,4-dione $\mathrm{DPP}(\mathrm{TBFu})_{2}$

Under inert atmosphere, to a solution of $5(2.2 \mathrm{~g}, 3.2 \mathrm{mmol})$ in THF $(440 \mathrm{ml})$ and water $(110 \mathrm{ml})$ degassed with argon were added 2.06 eq of 2-(1-benzofuran-2-yl)-4,4,5,5-tetramethyl- 
1,3,2-dioxaborolane 6 (1.6 g, $6.6 \mathrm{mmol}), \mathrm{Na}_{2} \mathrm{CO}_{3}(0.7 \mathrm{~g}, 6.6 \mathrm{mmol}), \mathrm{PdCl}_{2}\left(\mathrm{PPh}_{3}\right)_{2}(0.09 \mathrm{~g}, 4 \%)$. The mixture was heated $2 \mathrm{~h}$ at $40{ }^{\circ} \mathrm{C}$ under inert atmosphere. After cooling to $\mathrm{rt}, 200 \mathrm{ml}$ of dichloromethane was added. The organic phase was washed with water and dried over $\mathrm{Na}_{2} \mathrm{SO}_{4}$. After removal of the solvent, the residue was purified by column chromatography $\left(\mathrm{SiO}_{2}\right.$; hex $\left./ \mathrm{CHCl}_{3} 1: 2\right)$ to give pure product $\mathrm{DPP}(\mathrm{TBFu})_{2}(2.03 \mathrm{~g}, 81 \%) .{ }^{1} \mathrm{H} \mathrm{NMR}\left(400 \mathrm{MHz}, \mathrm{CDCl}_{3}\right), \delta=$ $9.00(\mathrm{~d}, 2 \mathrm{H}, \mathrm{J}=4.2 \mathrm{~Hz}), 7.57-7.22(\mathrm{~m}, 10 \mathrm{H}), 7.01(\mathrm{~s}, 2 \mathrm{H}), 4.13-4.01(\mathrm{~m}, 4 \mathrm{H}), 1.94-1.93(\mathrm{~m}, 2 \mathrm{H}), 1.43-$ $1.22(\mathrm{~m}, 16 \mathrm{H}), 0.95-0.84(\mathrm{~m}, 12 \mathrm{H}) \mathrm{ppm}$; ${ }^{13} \mathrm{C} \mathrm{NMR}\left(400 \mathrm{MHz}, \mathrm{CDCl}_{3}\right), \delta=161.56,154.95,149.99$, 139.52, 137.89, 136.55, 129.52, 128.83, 125.42, 125.32, 123.50, 121.16, 111.25, 108.69, 103.62, 46.06, 39.26, 30.33, 28.52, 23.66, 23.11, 14.09, 10.55 ppm. HR-FT-MALDI-MS (DHB) m/ z: $756.3062\left(\mathrm{M}^{+}\right)$ requires. 756.30555. Anal. Calcd for $\mathrm{C}_{46} \mathrm{H}_{48} \mathrm{~N}_{2} \mathrm{O}_{4} \mathrm{~S}_{2}$ (757.01): C 72.98, H 6.39, N 3.7, O 8.45, S 8.47; Found C 72.94, H 6.45, N 3.84, S 8.39.

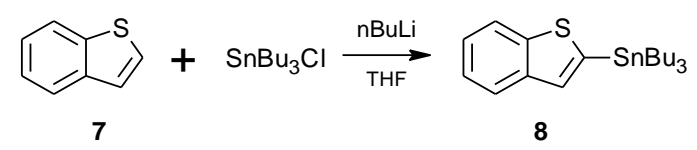

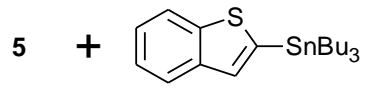

8

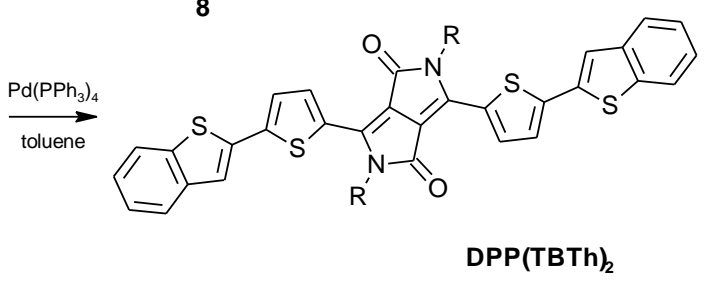

Scheme S2: DPP(TBTh $)_{2}$

Compound 8 was prepared as reported in the literature ${ }^{2-3}$.

3,6-bis[5-(benzothiofen-2-yl)thiophen-2-yl]-2,5-bis(2-ethylhexyl)-1H,2H,4H,5H-pyrrolo[3,4c]pyrrole-1,4-dione DPP(TBTh) 2

Compound $\mathrm{DPP}(\mathrm{TBTh})_{2}$ was prepared as reported in the literature 1.

Under inert atmosphere, to a solution of $5(5.25 \mathrm{~g}, 7.7 \mathrm{mmol})$ in toluene $(160 \mathrm{ml})$ degassed with argon were added 2.2 eq of 2-tributylstannylbenzo[b]thiophene 8 (6.65 g, 15.7 mmol) and $\mathrm{Pd}\left(\mathrm{PPh}_{3}\right)_{4}(1 \mathrm{~g}, 10 \%)$. The mixture was heated $24 \mathrm{~h}$ at $108^{\circ} \mathrm{C}$ under inert 
atmosphere. After cooling to $\mathrm{rt}, 200 \mathrm{ml}$ of dichloromethane was added and purified to plug chromatohraphy. After removal of the solvent, the residue was purified by column chromatography $\left(\mathrm{SiO}_{2} ;\right.$ hex $\left./ \mathrm{CHCl}_{2} 1: 2\right)$ to give pure product $\mathrm{DPP}(\mathrm{TBTh})_{2}(4.46 \mathrm{~g}, 73 \%) .{ }^{1} \mathrm{H}$ $\operatorname{NMR}\left(400 \mathrm{MHz}, \mathrm{CDCl}_{3}\right), \delta=8.96(\mathrm{~d}, 2 \mathrm{H}, J=4 \mathrm{~Hz}), 7.82-7.77(\mathrm{~m}, 4 \mathrm{H}), 7.56(\mathrm{~s}, 2 \mathrm{H}), 7.44(\mathrm{~d}, 2 \mathrm{H}, J=$ $4 \mathrm{~Hz}), 7.39-7.35(\mathrm{~m}, 4 \mathrm{H}), 4.08(\mathrm{dd}, 4 \mathrm{H}, J=3.3 \mathrm{~Hz}, J=7.7 \mathrm{~Hz}), 1.56(\mathrm{~m}, 2 \mathrm{H}), 1.44-1.25(\mathrm{~m}, 16 \mathrm{H})$, 0.96-0.89 (m, 12H) ppm; ${ }^{13} \mathrm{C}$ NMR (400 MHz, $\left.\mathrm{CDCl}_{3}\right), \delta=161.62,150.9,143.99$, 139.52, 136.55, 134.42 , 129.32, 125.42, 125.12, 123.80, 122.24, 121.36, 114.25, 108.69, 46.08, 31.26, 28.52, 23.41, 23.11, 22.06, 14.09, 10.75 ppm. HR-FT-MALDI-MS (DHB) m/z: $7858.2600\left(\mathrm{M}^{+}\right)$requires. 788.2599.

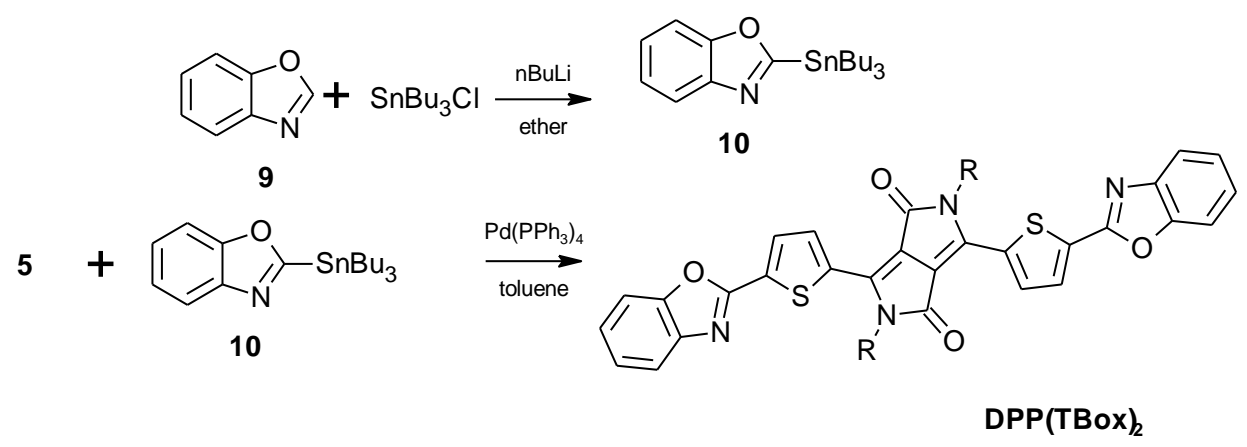

Scheme S3: DPP(TBox $)_{2}$

Compound 10 was prepared as reported in [5]. 3,6-bis[5-(1-benzoxazol-2-yl)thiophen-2-yl]-2,5bis(2-ethylhexyl)-1H,2H,4H,5H-pyrrolo[3,4-c]pyrrole-1,4-dione DPP(TBox) 2.

Under inert atmosphere, to a solution of $5(4.38 \mathrm{~g}, 6.4 \mathrm{mmol})$ in toluene $(120 \mathrm{ml})$ degassed with argon were added $2.2 \mathrm{eq}$ of 2-tributylstannylbenzoxazole 10 (5.39 g, $13.2 \mathrm{mmol})$ and $\mathrm{Pd}\left(\mathrm{PPh}_{3}\right)_{4}(0.742 \mathrm{~g}, 10 \%)$. The mixture was heated $24 \mathrm{~h}$ at $108{ }^{\circ} \mathrm{C}$ under inert atmosphere. After cooling to rt, $200 \mathrm{ml}$ of dichloromethane was added and purified to plug chromatohraphy. After removal of the solvent, the residue was purified by column chromatography $\left(\mathrm{SiO}_{2}\right.$; hex $/ \mathrm{CHCl}_{2}$ 1:2) to give pure product DPP(TBox $)_{2}(1.98 \mathrm{~g}, 57 \%) .{ }^{1} \mathrm{H} \mathrm{NMR}\left(400 \mathrm{MHz}, \mathrm{CDCl}_{3}\right), \delta=$ $9.08(\mathrm{~d}, 2 \mathrm{H} . J=4 \mathrm{~Hz}), 8.01(\mathrm{~d}, 2 \mathrm{H} . J=4 \mathrm{~Hz}), 7.78-7.76(\mathrm{~m}, 2 \mathrm{H}), 7.60-7.57(\mathrm{~m}, 2 \mathrm{H}), 7.40-7.38(\mathrm{~m}$, $4 \mathrm{H}), 4.13-4.10(\mathrm{~m}, 4 \mathrm{H}), 1.94(\mathrm{~m}, 2 \mathrm{H}), 1.44-1.25(\mathrm{~m}, 16 \mathrm{H}), 0.94-0.86(\mathrm{~m}, 12 \mathrm{H}) \mathrm{ppm}$; ${ }^{13} \mathrm{C}$ NMR $(400$ 
$\left.\mathrm{MHz}, \mathrm{CDCl}_{3}\right), \delta=161.49,157.78,150.62,164.58,142.00,140.02,136.52,133.71,133.08$, 130.46, 125.88, 125.13, 120.16, 110.64, 109.74, 46.21, 39.25, 30.16, 29.69, 28.39, 23.57, 23.06, 14.03, 10.47 ppm. HR-FT-MALDI-MS (DHB) m/z: $758.2951\left(\mathrm{M}^{+}\right)$requires. 758.2961.

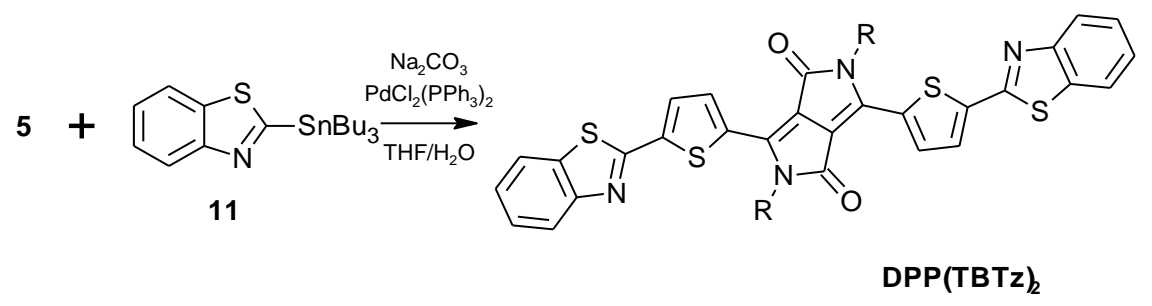

Scheme S4: DPP(TBTz $)_{2}$

3,6-bis[5-(1,3-benzothiazol-2-yl)thiophen-2-yl]-2,5-bis(2-ethylhexyl)-1H,2H,4H,5H-pyrrolo[3,4c]pyrrole-1,4-dione DPP(TBTz $)_{2}$.

Under inert atmosphere, to a solution of $5(3.8 \mathrm{~g}, 5.61 \mathrm{mmol})$ in toluene $(120 \mathrm{ml})$ degassed with argon were added 2.21 eq of 2-tributylstannyl-1,3-benzothiazole 11 (5.00 g, 11.79 $\mathrm{mmol})$ and $\mathrm{Pd}\left(\mathrm{PPh}_{3}\right)_{4}(0.708 \mathrm{~g}, 0.612 \mathrm{mmol})$. The mixture was heated $24 \mathrm{~h}$ at $115^{\circ} \mathrm{C}$ under inert atmosphere. After cooling to $\mathrm{rt}, 200 \mathrm{ml}$ of dichloromethane was added and purified to plug chromatohraphy $\left(\mathrm{SiO}_{2} ;\right.$ hex $/ \mathrm{CHCl}_{3}$ 1:3). After removal of the solvent, the residue was purified by column chromatography $\left(\mathrm{SiO}_{2}\right.$; hex $\left./ \mathrm{CHCl}_{3} 1: 7\right)$ to give pure product $\mathrm{DPP}(\mathrm{TBTz})_{2}(1.69 \mathrm{~g}, 44$ \%). ${ }^{1} \mathrm{H}$ NMR $\left(400 \mathrm{MHz}, \mathrm{CDCl}_{3}\right), \delta=9.06(\mathrm{~d}, 2 \mathrm{H} . J=4 \mathrm{~Hz}), 8.05(\mathrm{~d}, 2 \mathrm{H} . J=4 \mathrm{~Hz}), 7.88(\mathrm{~m}, 2 \mathrm{H})$, $7.73(\mathrm{~m}, 2 \mathrm{H}), 7.53-7.38(\mathrm{~m}, 4 \mathrm{H}), 4.12-4.11(\mathrm{~m}, 4 \mathrm{H}), 1.95$ (m, 2H), 1.41-1.25 (m, 16H), 0.94-0.87 (m, 12H) ppm; ${ }^{13} \mathrm{C}$ NMR (400 MHz, $\left.\mathrm{CDCl}_{3}\right), \delta=161.55,159.80,153.75,141.72,140.04,136.59,135.11$, 132.23, 129.11, 126.79, 125.82, 123.34, 121.58, 109.58, 46.14, 39.29, 30.22, 29.70, 28.44, 23.60, 23.10, 14.07, 10.51 ppm. HR-FT-MALDI-MS (DHB) m/z: $790.2497\left(\mathrm{M}^{+}\right)$requires. 790.2504. 
Notes to active layer optimization

We tested various other types of solvents but compared to chloroform they typically worsen the film homogeneity. 1,8-diiodooctane (DIO) as a solvent additive did not importantly affected the results. Annealing at higher temperatures led to degradation of OPV structure.

\section{NanoESCA}

Qantitative analysis of XPS core level spectra C 1s, N 1s, O 1s and S $2 p$ confirmed nominal stoichiometry of samples and resolved non-equivalent oxygen atoms for $\operatorname{DPP}(\mathrm{TBFu})_{2}$ and $\mathrm{DPP}(\mathrm{TBOx})_{2}$ and nitrogen atoms for DPP(TBOx $)_{2}$ and DPP(TBTz $)_{2}$, respectively (Figs. S3, S4).

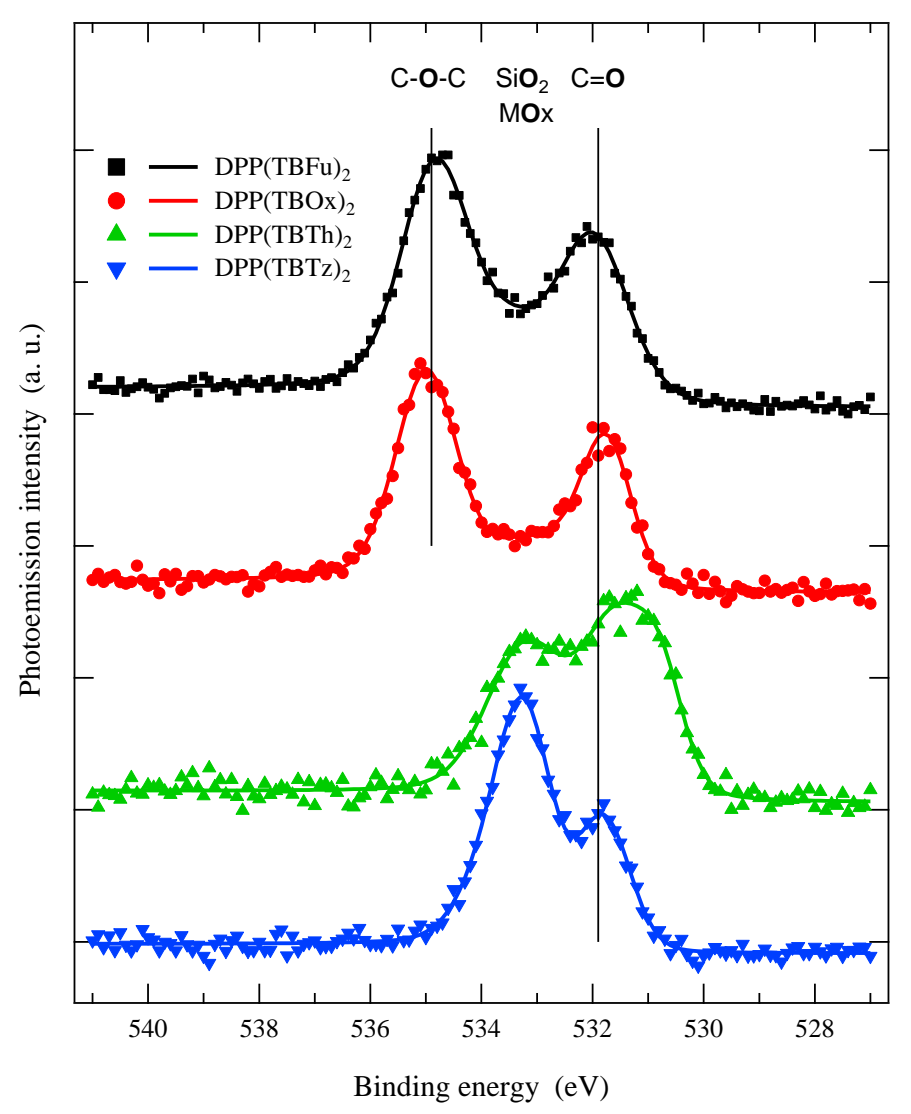

Fig. S1: XPS O 1s core level spectra. 


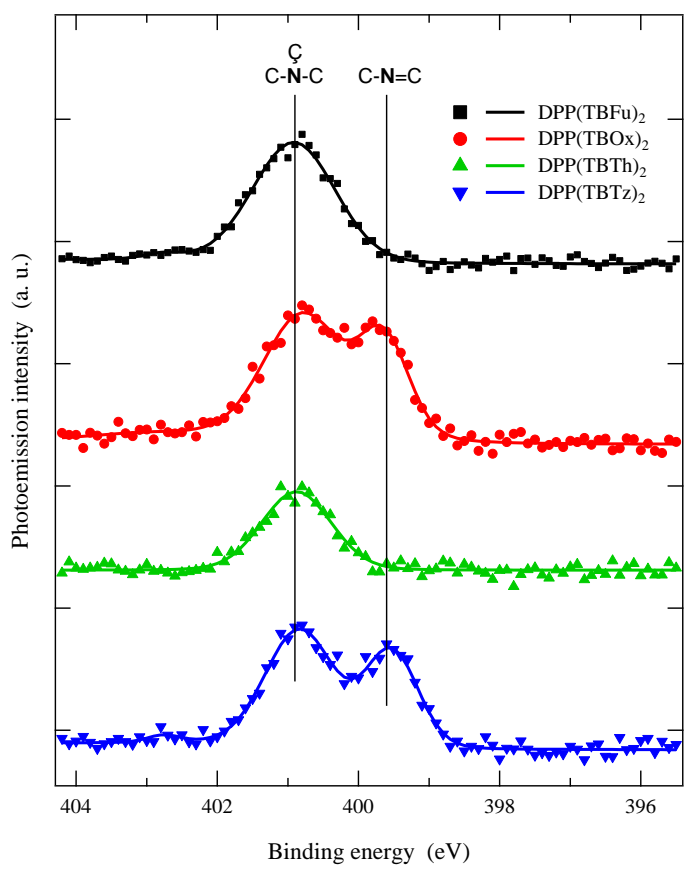

Fig. S2: XPS N 1s core level spectra.
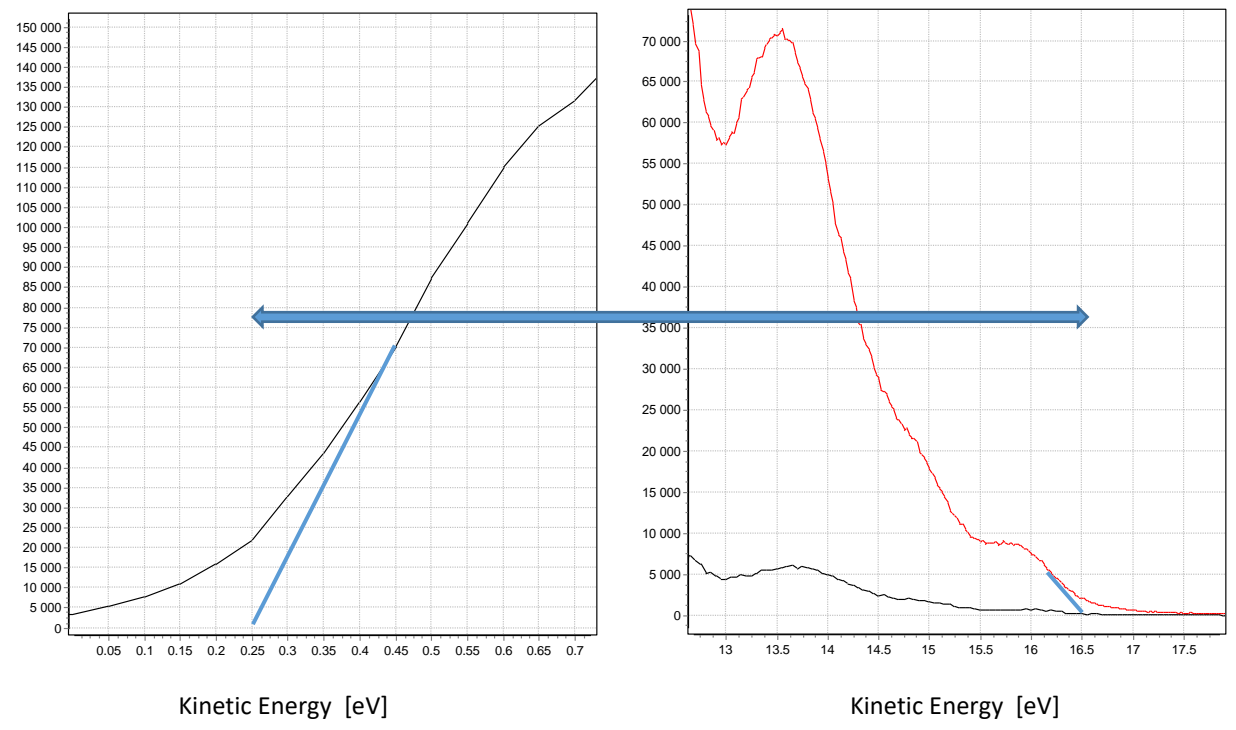

Fig. S3: UPS data and way of calculation of $\mathrm{DPP}(\mathrm{TBFu})_{2}$ ionization energy: spectrum width is $16.55 \mathrm{eV}-0.25 \mathrm{eV}=16.3 \mathrm{eV}$ and corresponding ionization energy is then $4.9 \mathrm{eV}$. The ionization potential/ HOMO level value is the difference between the excitation energy $21.2 \mathrm{eV}$ and the width of the spectra (cutoff position + valence band onset) as shown in the Fig. S4 (for DPP(TBTz) 2 ). The red curve was measured at the same conditions, but with higher gain than the black one. 


\section{Atomic Force Microscopy (AFM)}

Comparison of AFM probe images of as prepared and annealed blends DPP: $\mathrm{PC}_{70} \mathrm{BM}$ was made. All investigated DPP materials were checked by AFM and in all cases after annealing the crystallization increasing was clearly visible. Figs (S1, S2) shows height of the surface of samples containing $\mathrm{DPP}(\mathrm{TBTz})_{2}$. The long shape crystals are $\mathrm{DPP}(\mathrm{TBTz})_{2}$. After annealing the DPP crystallization in DPP: $\mathrm{PC}_{70} \mathrm{BM}$ blend significantly raised. Specially, AFM confirmed that crystallization increased after annealing in the case of $\mathrm{DPP}(\mathrm{TBOx})_{2}$ : $\mathrm{PC}_{70} \mathrm{BM}$ blend (Root mean square (RMS) roughness increased after annealing from 4.2 to 5.7$)$ and $\mathrm{DPP}(\mathrm{TBTz})_{2}: \mathrm{PC}_{70} \mathrm{BM}$ blend (RMS roughness increased after annealing from 3.7 to 5.9).

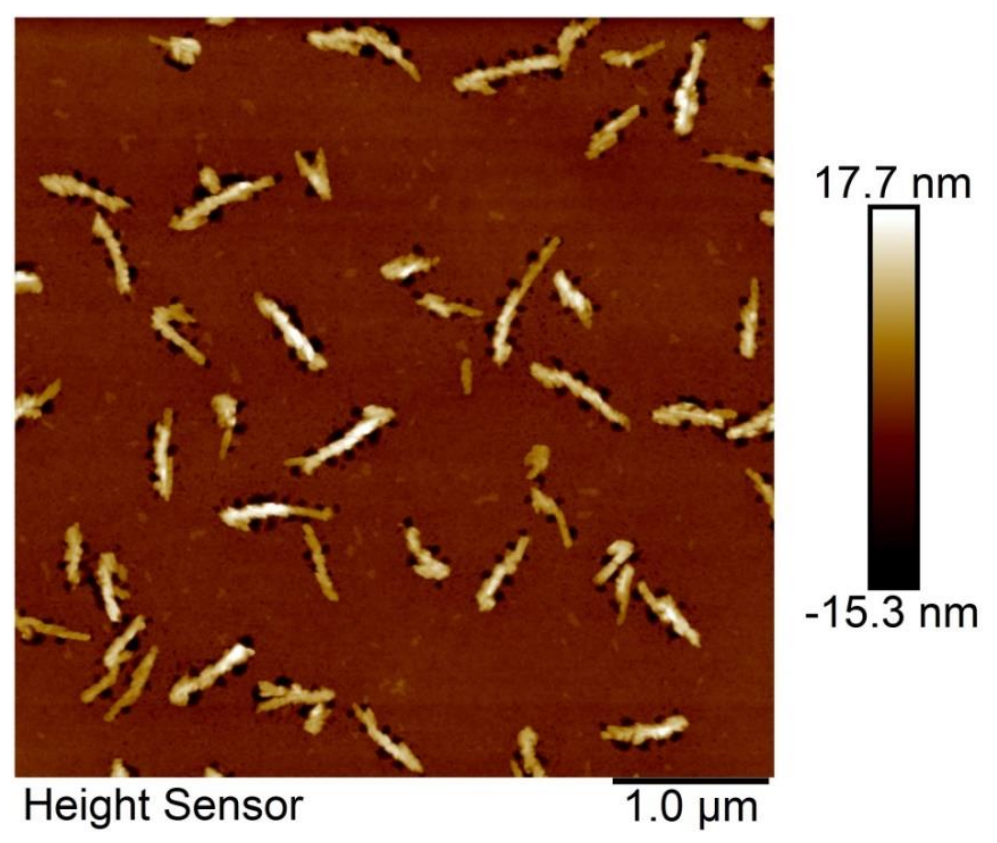

Fig. S4: AFM of as prepared DPP(TBTz) 2.: $P C_{70} B M$ sample. 


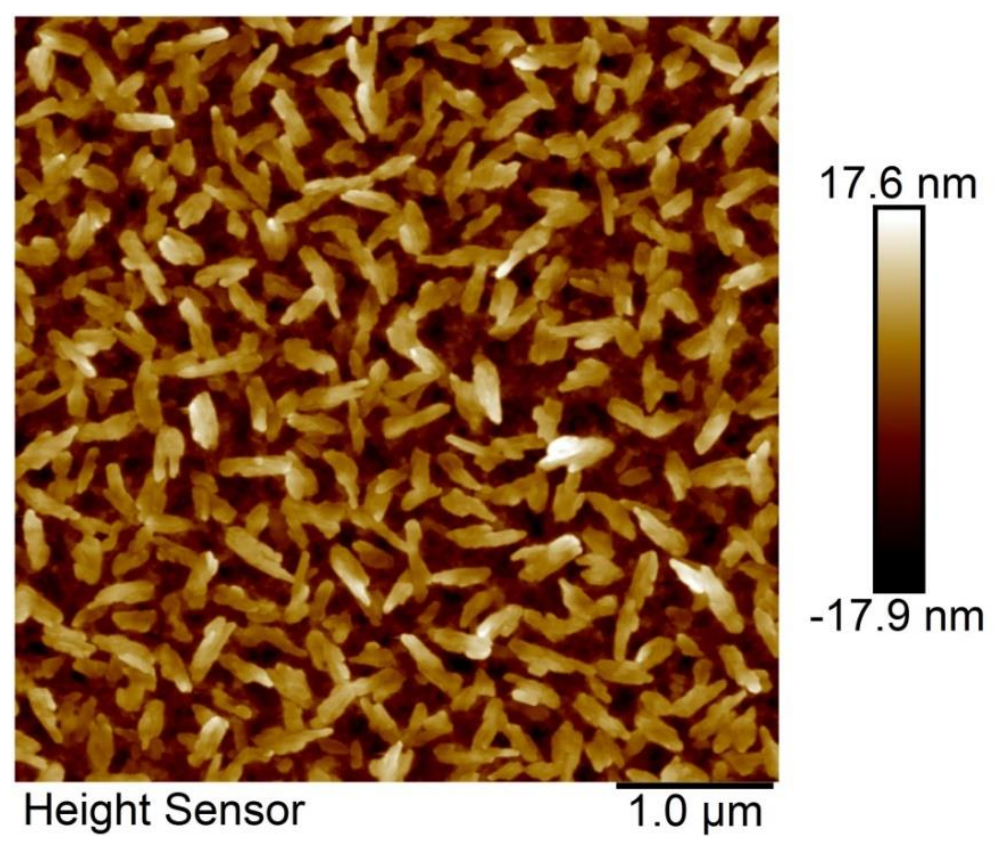

Fig. S5: AFM of annealed DPP(TBTz)2.: PC $C_{70} B M$ sample.

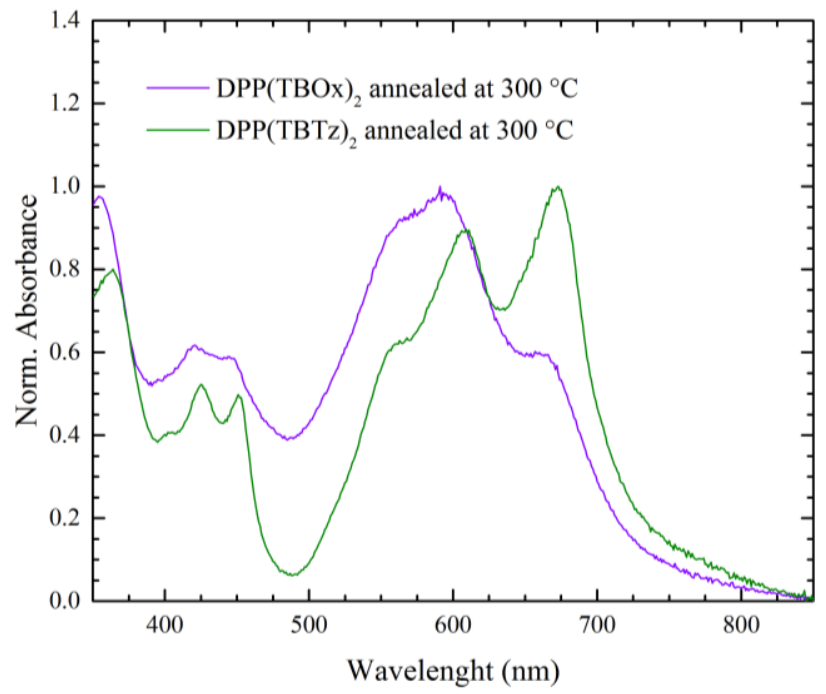

Fig. S6: Absorption spectra of $\mathrm{DPP}(\mathrm{TBOx})_{2}$ and $\mathrm{DPP}(\mathrm{TBTz})_{2}$ layers after annealing at $300{ }^{\circ} \mathrm{C} 2 \mathrm{~min}$. 

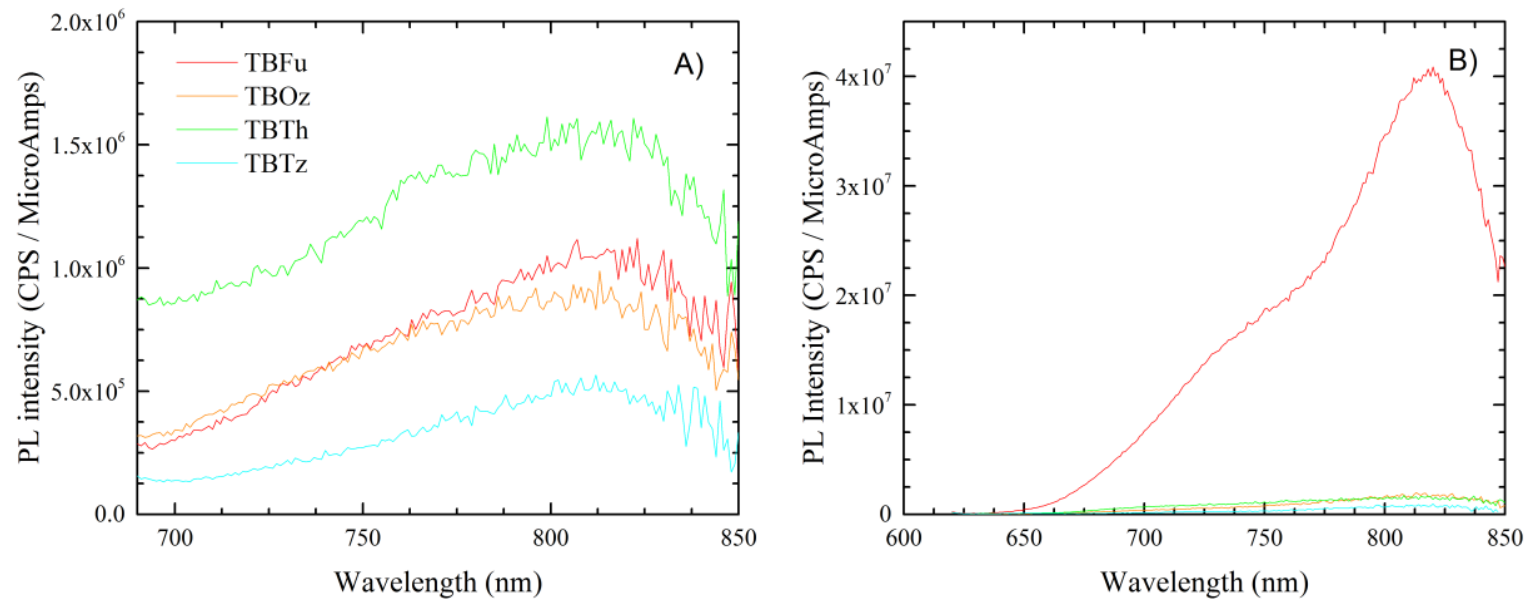

Fig. S7: Impact of DPPs layer annealing on fluorescence intensity. A) as-cast layers, B) annealed layers at $130^{\circ} \mathrm{C}$. 


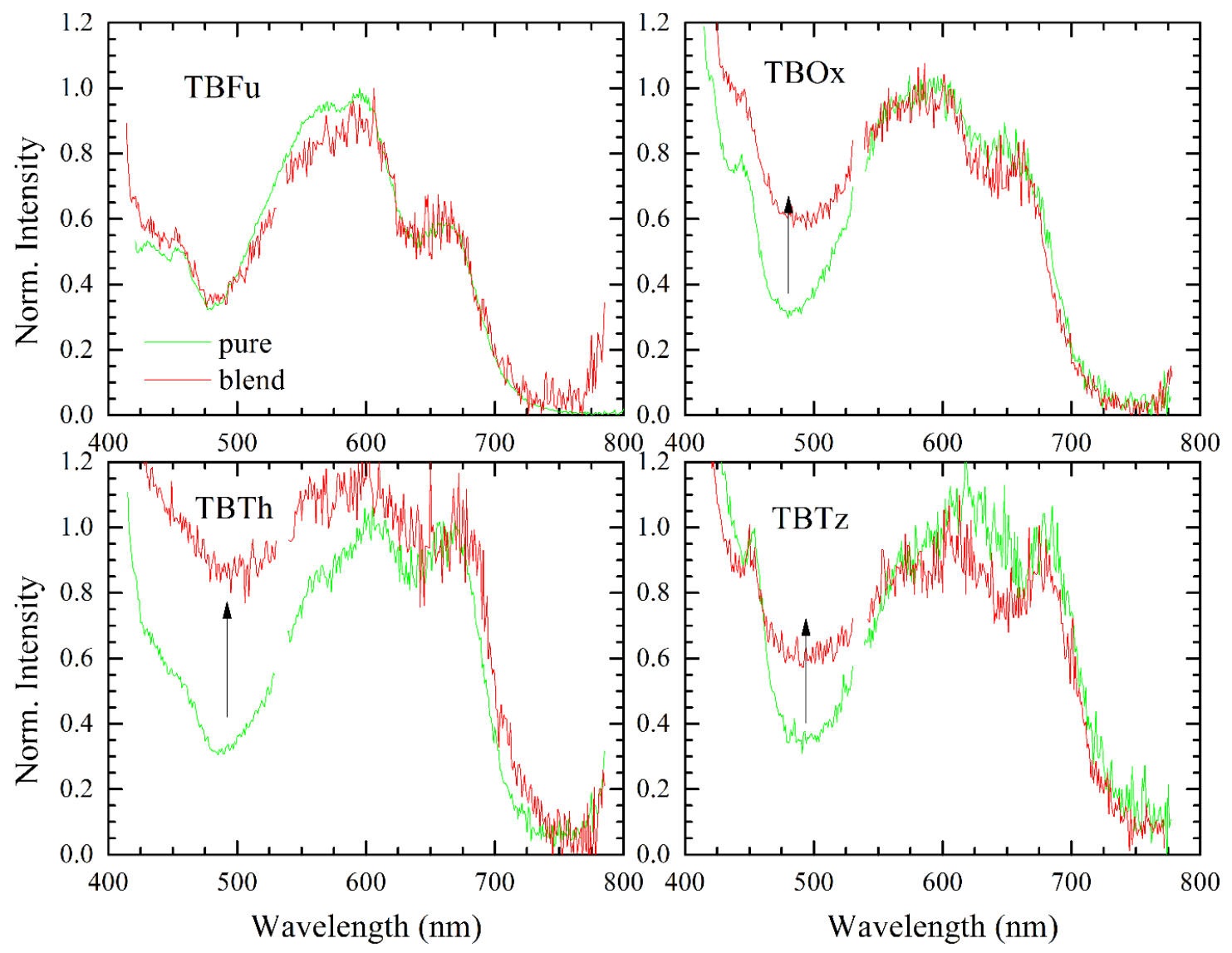

Fig. S8: Fluorescence excitation spectra of pure DPP derivatives (green) and their blends with $P C_{70} B M$ (red). The arrows show the regions with enhanced signal due to absorption of the excitation light by $P C_{70} B M$.

\section{Transient absorption fit quality summaries}

Figs. S9-S16 show the summary of experimental results transient absorption spectrotemporal evolution in a given composite sample observed in the vis- or NIR-probe spectral regions following the excitation with light pulse. The material and spectral region is indicated in the individual figure caption. The format of the figures is identical: upper left-panel: circles show the representative differential spectra recorded at delay times indicated in the legend; upperright panel: circles show the representative time evolutions of the TA signal at probe wavelengths given in the legend; lower-left panel: the resulting Species-Associated Differential Spectra (SADS) obtained by application global analysis with two-compartment sequential kinetic model - the corresponding lifetimes are shown in the legend. The lower-right panel shows the evolution of the fractions of the corresponding SADSs, respective of the line color of 
the SADS plot. The quality of the fit can be judged from the model curves shown with full lines in the upper panels together with the experimental data, respective of the symbol color.
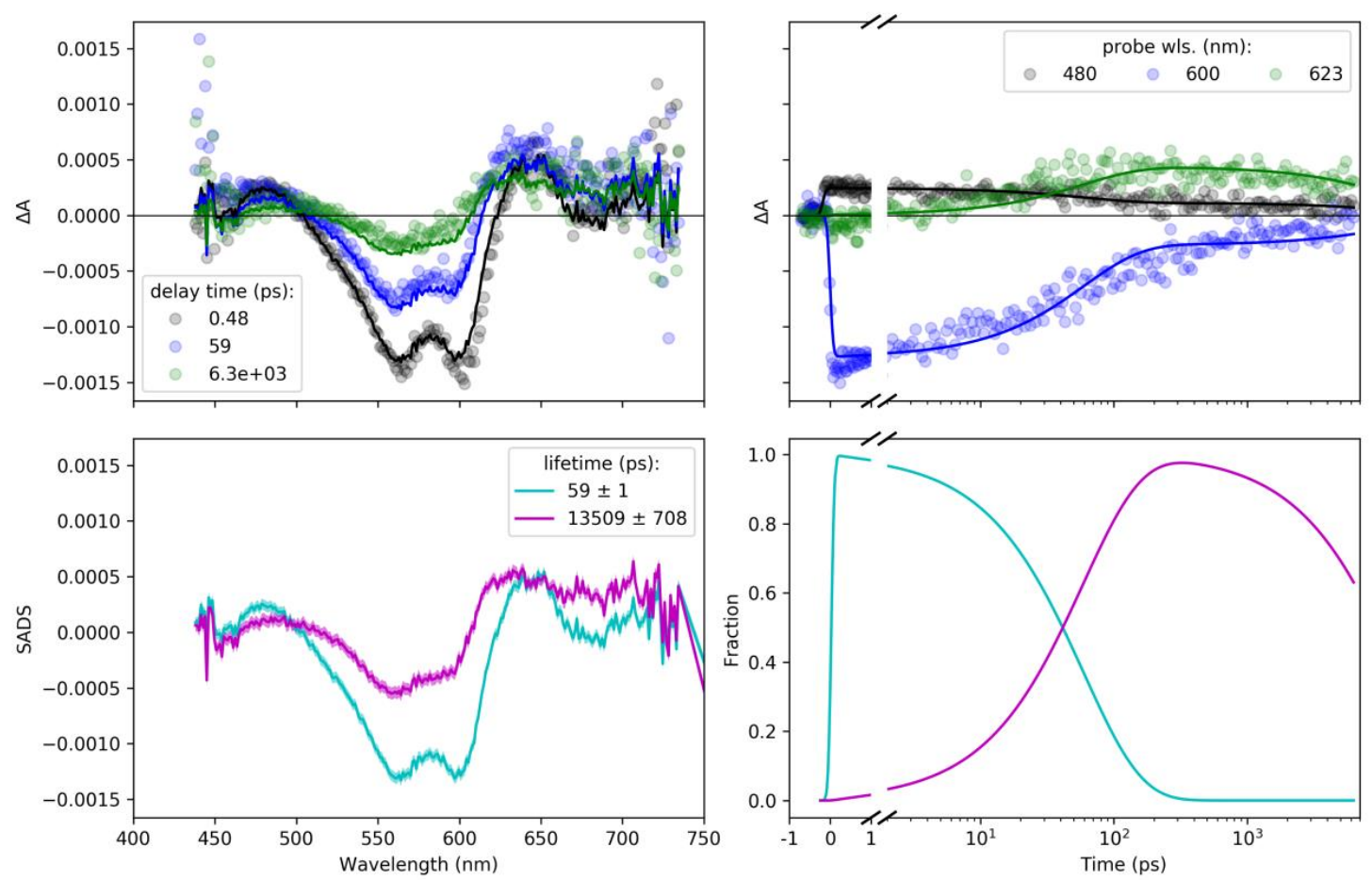

Fig. S9: Material BHJ132; vis-probe TA data. 

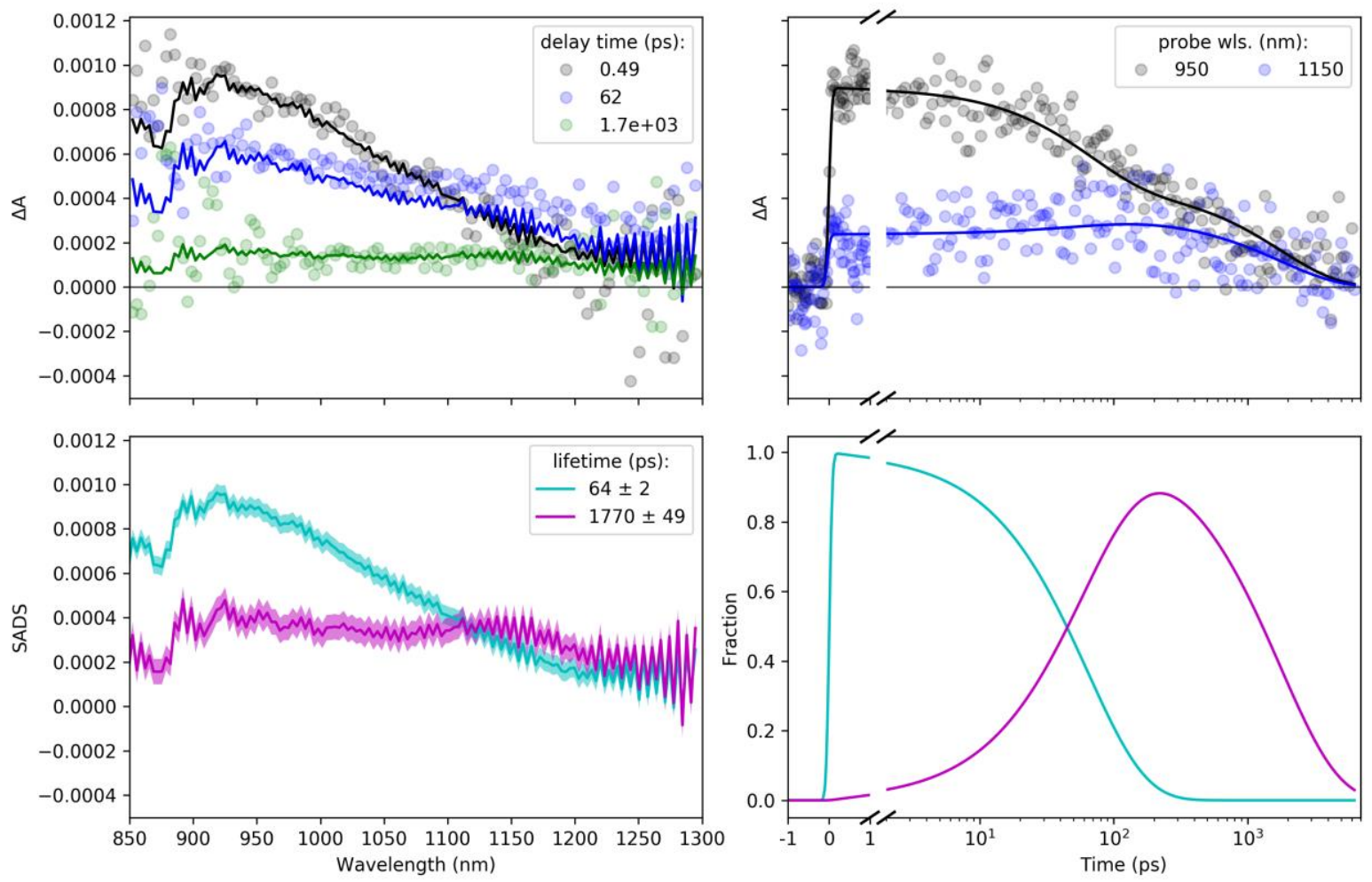

Fig. S10: Material BHJ132; NIR-probe TA data.
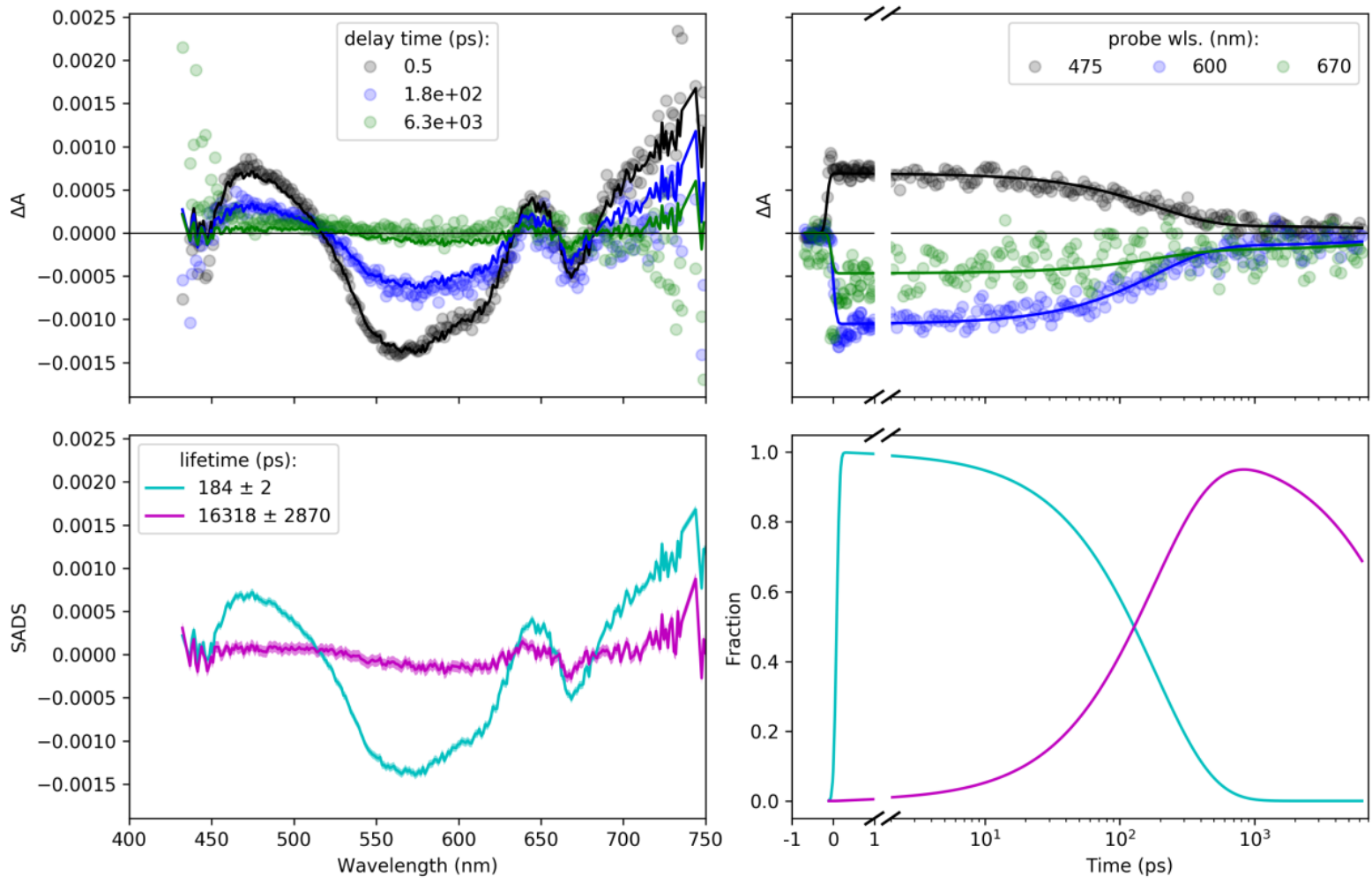

Fig. S11: Material BHJ140; vis-probe TA data. 

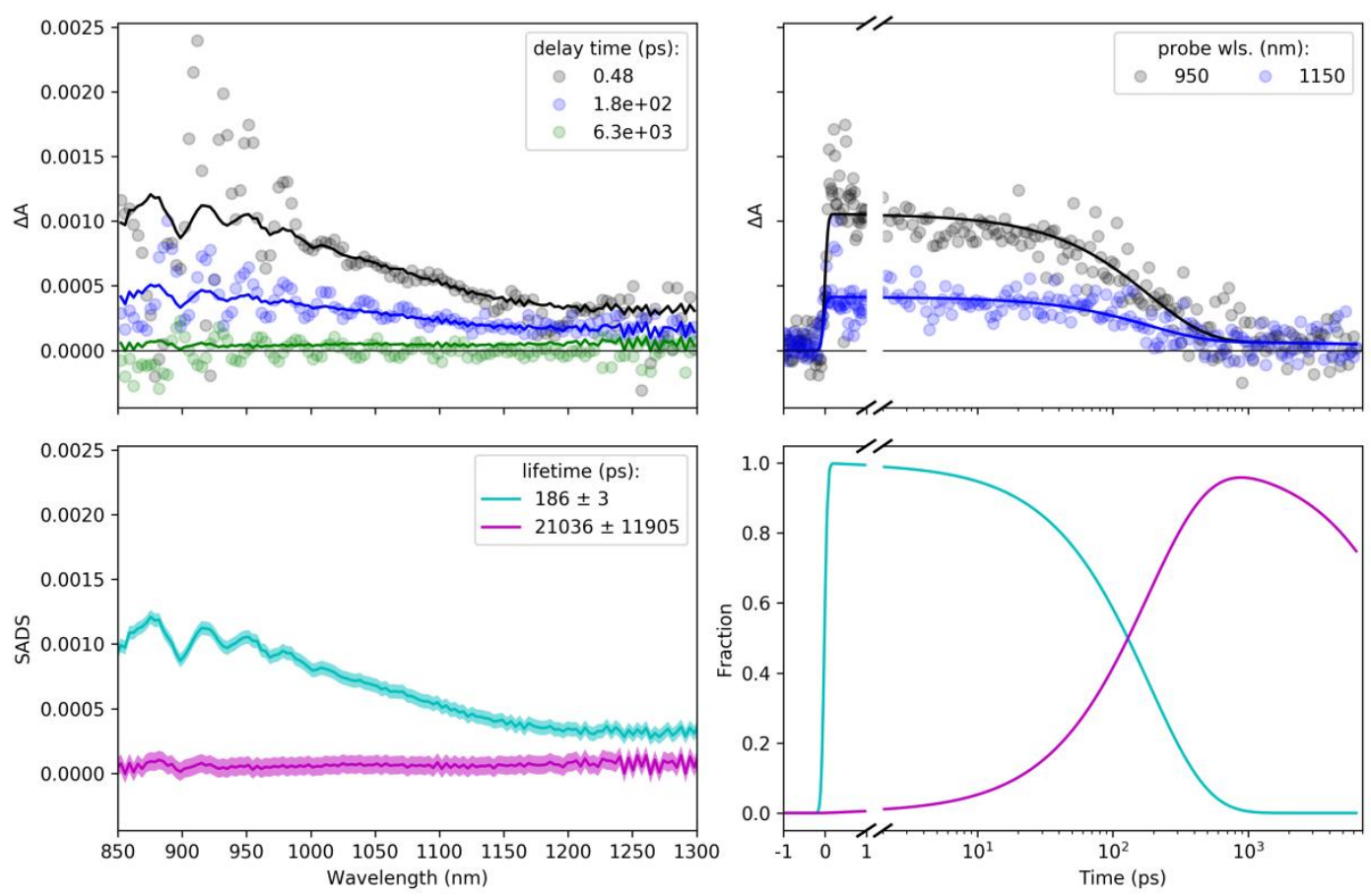

Fig. S12: Material BHJ140; NIR-probe TA data.
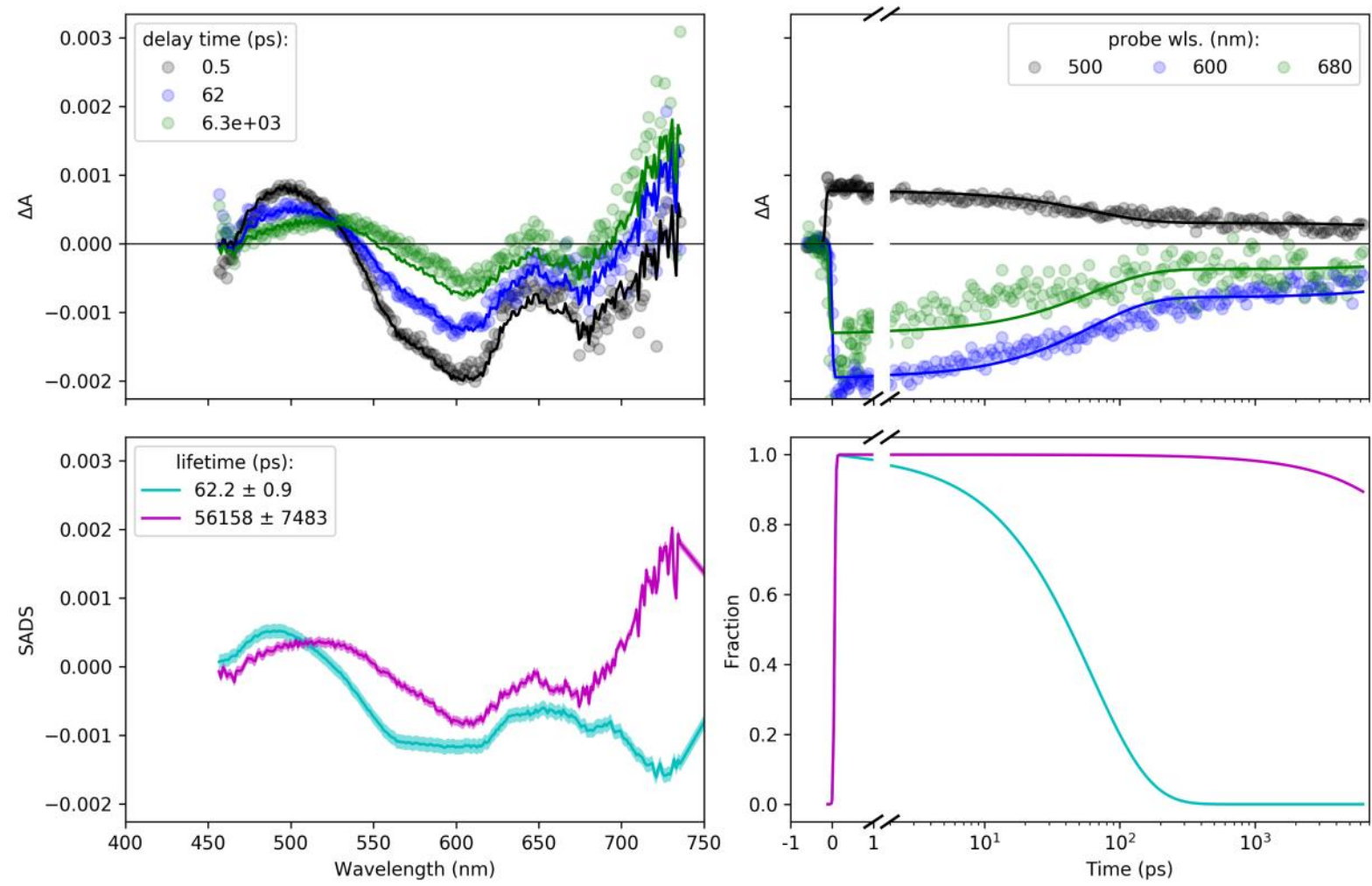

Fig. S13: Material BHJ151; vis-probe TA data. 

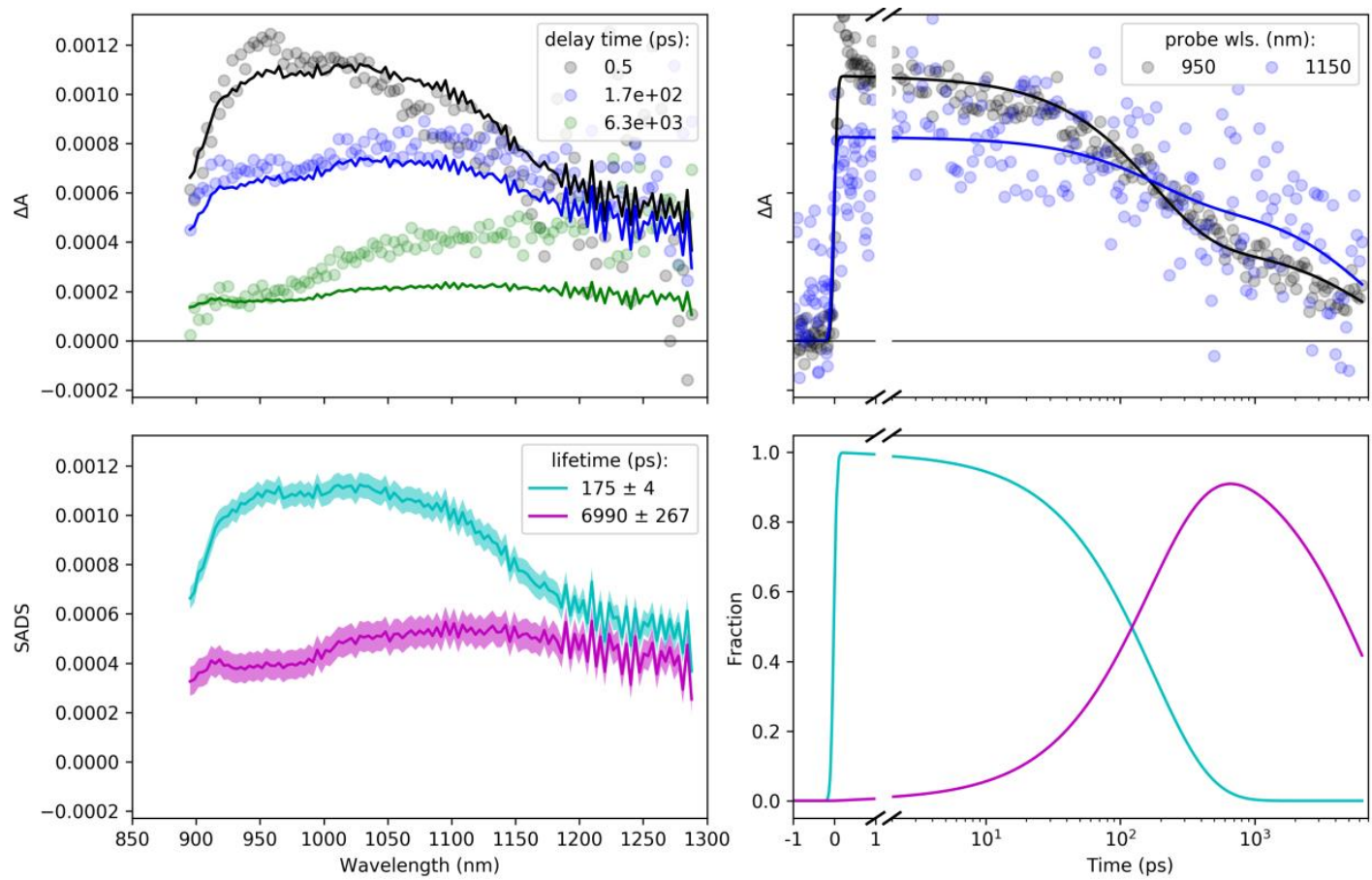

Fig. S14: Material BHJ151; NIR-probe TA data.
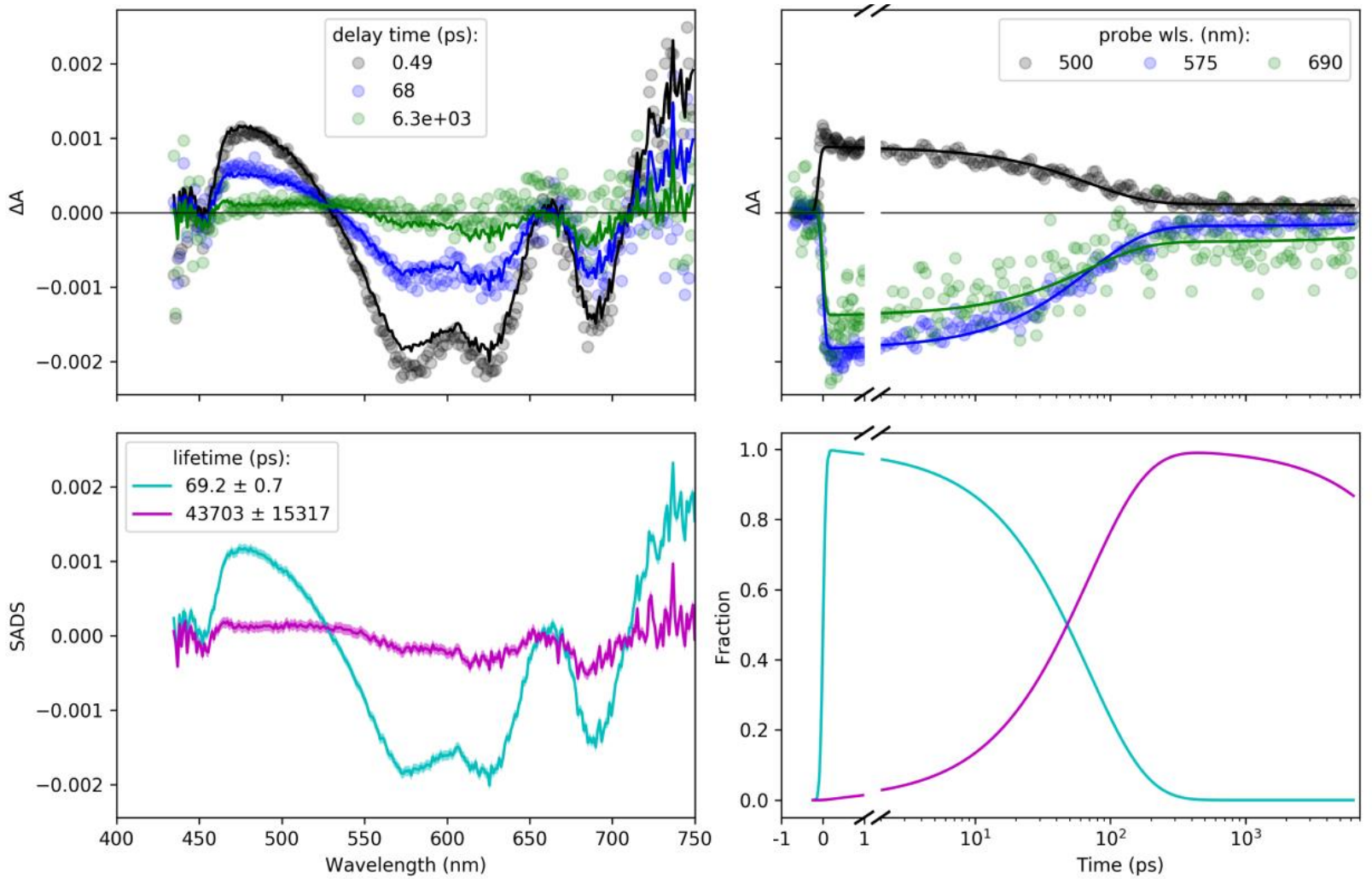

Fig. S15: Material BHJ184; vis-probe TA data. 

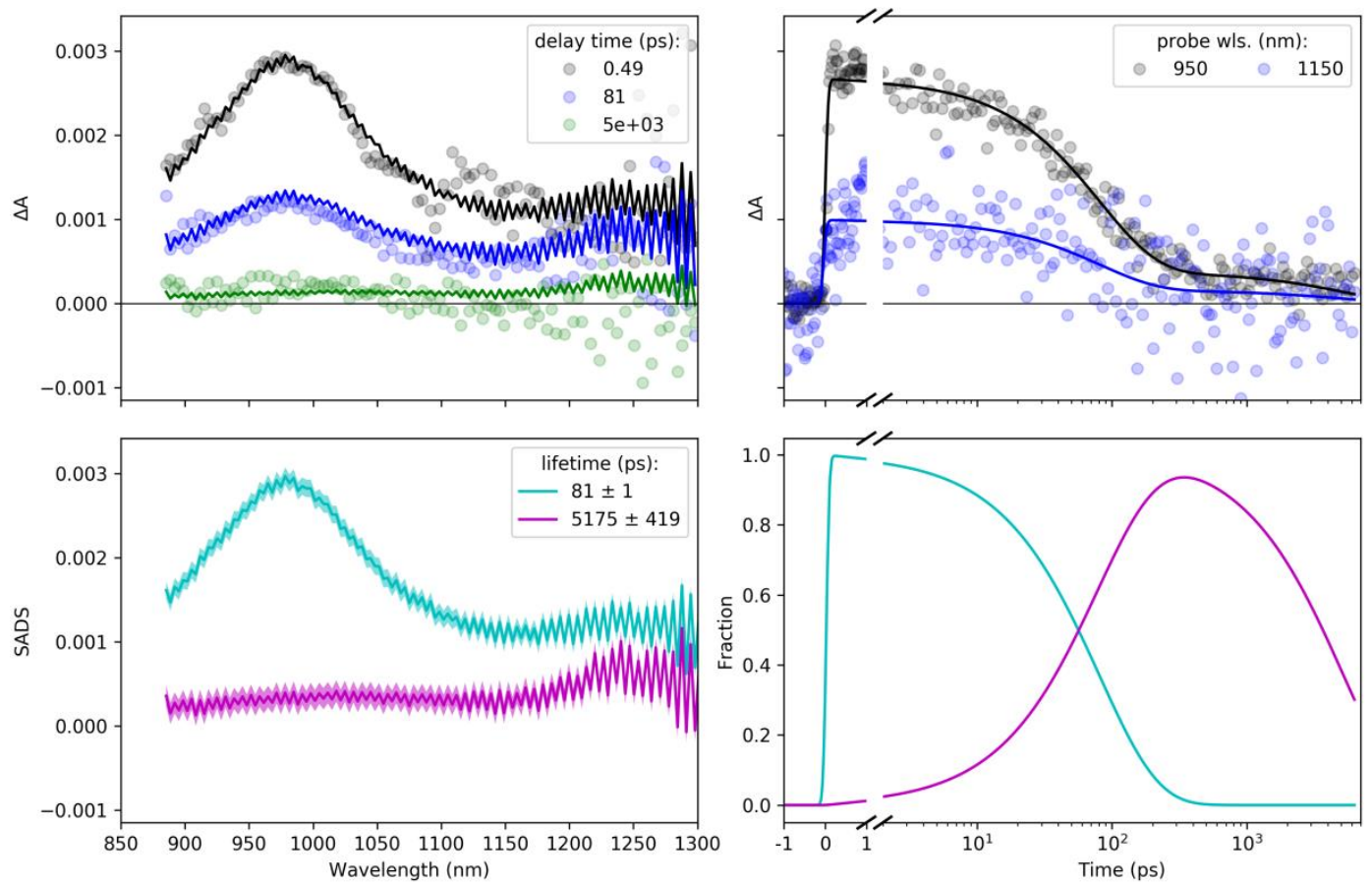

Fig. S16: Material BHJ184; NIR-probe TA data.

\section{Optoelectrical characteristics}

Table S1: Serial and shunt resistance of OPV devices.

As cast

Annealed

\begin{tabular}{|l|cccc|} 
Derivate & $\boldsymbol{R}_{\mathbf{S}}\left(\boldsymbol{\Omega c m}^{2}\right)$ & $\boldsymbol{R}_{\mathbf{S h}}\left(\mathbf{k} \boldsymbol{\Omega} \mathbf{c m}^{2}\right)$ & $\boldsymbol{R}_{\mathbf{S}}\left(\mathbf{\Omega c m}^{2}\right)$ & $\boldsymbol{R}_{\mathbf{S h}}\left(\mathbf{k} \boldsymbol{\Omega} \mathbf{c m}^{2}\right)$ \\
\hline DPP(TBFu $)_{2}$ & 111 & 10 & 39 & 10 \\
DPP(TBOx $)_{2}$ & 273 & 21 & 158 & 21 \\
DPP(TBTh $)_{2}$ & 49 & 12 & 11 & 7 \\
DPP(TBTz $)_{2}$ & 529 & 16 & 52 & 29 \\
\hline
\end{tabular}

Table S2: The best achieved parameters on prepared photovoltaic devices from studied DPP materials blended with PC $_{70} B M$ with PEDOT:PSS as hole transport layer.

As cast

Thermal annealing at $130{ }^{\circ} \mathrm{C}$

\begin{tabular}{|l|cccc|cccc|} 
DPP & $J_{\mathrm{SC}}\left(\mathrm{mA} / \mathrm{cm}^{2}\right)$ & $V_{\mathrm{OC}}(\mathrm{mV})$ & $F F(\%)$ & $\eta(\%)$ & $J_{\mathrm{SC}}\left(\mathrm{mA} / \mathrm{cm}^{2}\right)$ & $V_{\mathrm{OC}}(\mathrm{mV})$ & $F F(\%)$ & $\eta(\%)$ \\
\hline TBFu & 1.6 & 884 & 28 & 0.4 & 9.2 & 837 & 41 & 3.2 \\
TBOx & 0.8 & 605 & 27 & 0.1 & 1.1 & 597 & 29 & 0.2 \\
TBTh & 4.9 & 778 & 32 & 1.2 & 6.1 & 738 & 35 & 1.6 \\
TBTz & 0.4 & 601 & 27 & 0.1 & 1.7 & 560 & 29 & 0.3 \\
\hline
\end{tabular}




\section{Electroluminescence}
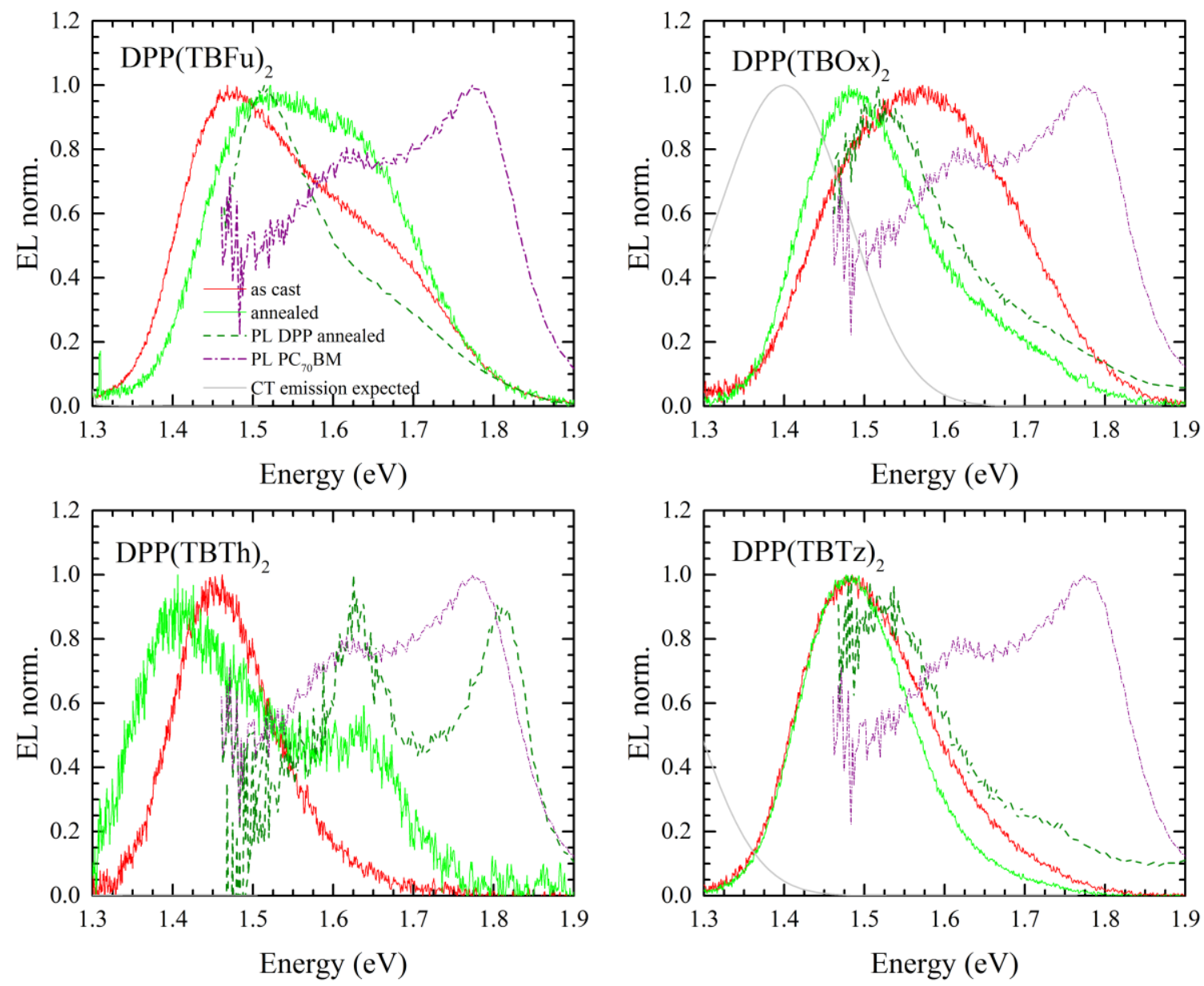

Fig. S17: Electroluminescence spectra of as cast OPV (red line) and annealed devices (green line) compared with fluorescence spectra of annealed DPP (dark green dashed line) and $P C_{70} B M$ layers (purple dashed line). The grey line represents the expected CT emission band estimated from molecular energetic levels.

Electroluminescence spectra were captured for possibility of emission from CT state observation. Devices were characterized as cast and after thermal annealing. All as cast devices, except of device from $\mathrm{DPP}(\mathrm{TBOx})_{2}$, have emission maximum at $1.48 \mathrm{eV}$. These spectra are very similar to photoluminescence spectra of as cast thin films, discussed in main text. The as cast device from $\mathrm{DPP}(\mathrm{TBOx})_{2}$ showed wide peak with maximum at $1.58 \mathrm{eV}$. This peak is probably composition of two peaks. Second peak with maximum about $1.65 \mathrm{eV}$ is also presented in spectrum of the as cast $\mathrm{DPP}(\mathrm{TBFu})_{2}$ device. 
After annealing, electroluminescence spectrum of $\mathrm{DPP}(\mathrm{TBOx})_{2}$ and $\mathrm{DPP}(\mathrm{TBTz})_{2}$ devices have practically same shape as photoluminescence spectra. The spectrum of DPP $(\mathrm{TBFu})_{2}$ device is narrower with more dominant emission from vibronic peak with higher energy than as cast device. It is contrast to photoluminescence spectra, where the relaxation from lower vibronic levels are suppressed due to formation of H-aggregates. On other hand same grow of electroluminescence intensity at $1.65 \mathrm{eV}$ in spectrum of annealed device from $\mathrm{DPP}(\mathrm{TBTh})_{2}$ is expected, because as photoluminescence characterizations shown, this material forms Jaggregates with dominant 0-0 transition. The comparison of fluorescence spectrum of $\mathrm{DPP}(\mathrm{TBTh})_{2}$ with electroluminiscence spectrum in plot on Fig. S17 is showing absence of zero phonon transition in electroluminescence spectrum. First explanation is in reabsorption of photons with this energy by active layer.

More detail discussion about origin these spectra is hard due to spectral overlap of possible emission from DPPs singlets $\left(E_{\operatorname{maxPL}} \approx 1.5 \mathrm{eV}\right.$ and $\left.\approx 1.8 \mathrm{eV}\right)$, fullerene singlet $\left(E_{\operatorname{maxPL}} \approx 1.8\right.$ $\mathrm{eV})$ and fullerene triplet $\left(E_{\mathrm{T}}=1.5 \mathrm{eV}{ }^{4}, E_{\mathrm{T}}(\right.$ emission $\left.\max )=1.55 \mathrm{eV}{ }^{5}\right)$. Thus these electroluminescence spectra without other experiments cannot be exactly described. However possible CT states emission peaks positions were estimated from CT state energy derived from IP of DPPs determined by nanoESCA and PC ${ }_{70} \mathrm{BM}$ electron affinity, see Table 1 in main text. It is expected that CT emission maximum will be $0.2-0.3 \mathrm{eV}$ lower than $E_{\mathrm{CT}}$ due to reorganization energy ${ }^{6}$, it means in the best case in range $1.0 \mathrm{eV}$ for device from $\mathrm{DPP}(\mathrm{TBTh})_{2}$ to $1.4 \mathrm{eV}$ for device from $\mathrm{DPP}(\mathrm{TBOx})_{2}$. Simulated peak of CT emission is included in spectra on Fig. S17. According this data, CT state emission can be captured in cases of DPP(TBOx) $)_{2}$ and only particularly in cases of $\mathrm{DPP}(\mathrm{TBTz})_{2}$. It is needed to note that Ran et al. presented electroluminescence emission of $\mathrm{DPP}(\mathrm{TBFu})_{2}: \mathrm{PC}_{70} \mathrm{BM}$ device with maximum at $1.33 \mathrm{eV}$ assigned to CT state. Nevertheless all our presented electroluminescence spectra are consisted from peaks with maximum at higher energy than expected value and there are nothing significant shoulder pointing to other low energy emission band.

Thus detected electroluminescence spectra of all devices origin the most probably from only singlets and/or triplets of individual components of active layers. In summary, absence of CT states emission has a few explanation:

1) In case of $\mathrm{DPP}(\mathrm{TBFu})_{2}$ and $\mathrm{DPP}(\mathrm{TBTh})_{2} \mathrm{CT}$ electroluminescence is probably out of detected energy range. Moreover it was referred that singled emission is observed in optimized 
high efficient devices after phase separation and grow of materials crystallinity ${ }^{5}$. The presence of EL emission from CT states is more probable observed before annealing of devices, when donor and acceptor material are creating intimate mixture.

2) In case of $\mathrm{DPP}(\mathrm{TBOx})_{2}$ and $\mathrm{DPP}(\mathrm{TBTz})_{2}, \mathrm{CT}$ is unlikely due to small driving force and thus CT state emission wasn't detected nevertheless according to estimated energy of CT states seems to be CT state at the least particularly in detection range. It is consistent with determined poor efficiency of solar cells from these materials.
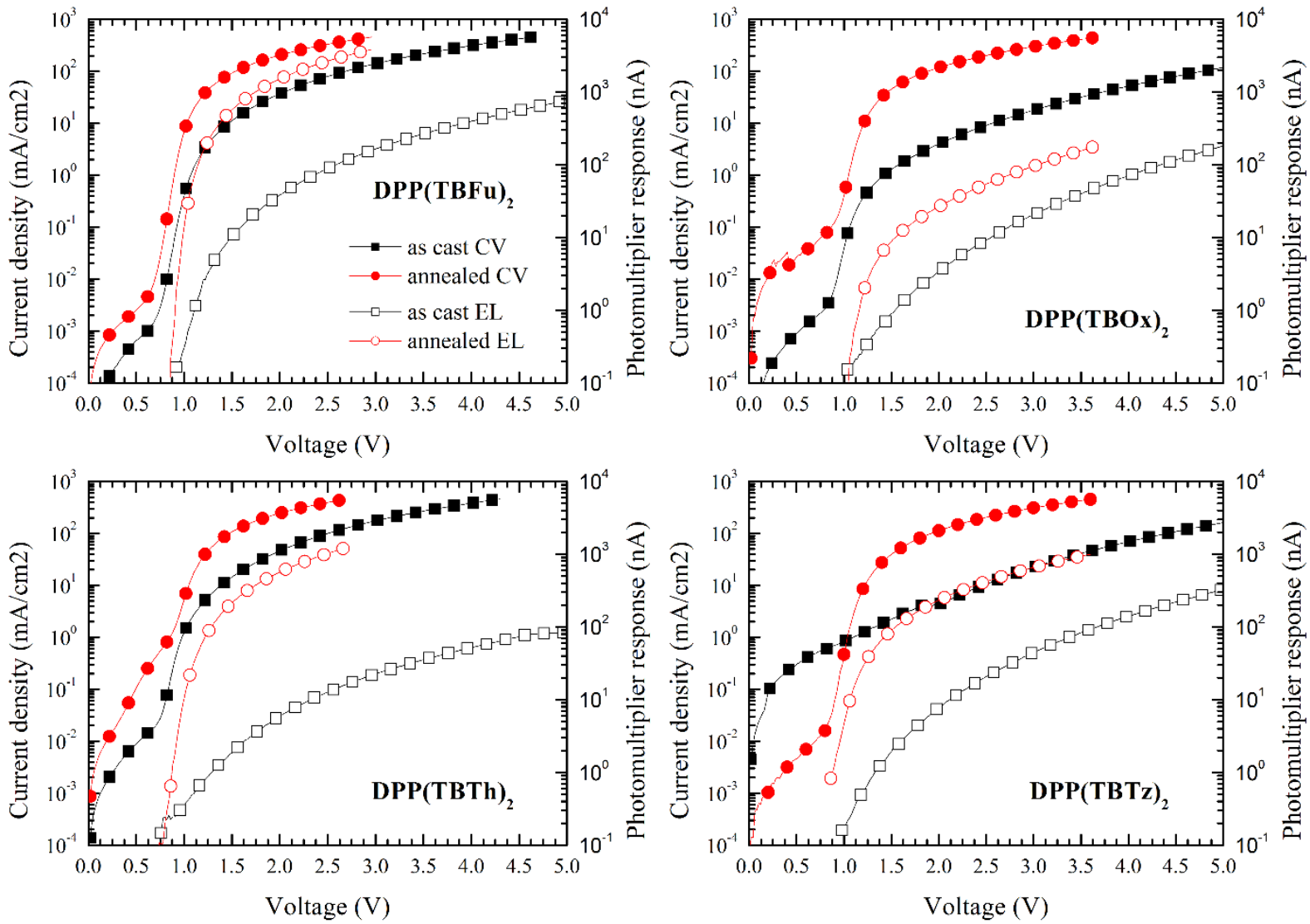

Fig S18: Dark current density-voltage characteristic of the OPV devices (filled symbols) and electroluminescence response (empty symbols) of the devices captured by photomultiplier. 


\section{References}

1. Ripaud, E.; Demeter, D.; Rousseau, T.; Boucard-Cetol, E.; Allain, M.; Po, R.; Leriche, P.; Roncali, J., Structure-Properties Relationships in Conjugated Molecules Based on Diketopyrrolopyrrole for Organic Photovoltaics. Dyes and Pigments 2012, 95, 126-133.

2. Chen, L.-H., Bithiophene Derivatives and Semiconductor Devices Comprising the Same United States Patent Application Publication (10) Pub. No.: US 2013/0168642 A1 2013.

3. Tsukuba, S., Selective Estrogen Receptor Modulators. Patent WO 2004/058682 (15.07.2004 Gazette 2004/29) 2002.

4. Veldman, D.; Meskers, S. C. J.; Janssen, R. A. J., The Energy of Charge-Transfer States in Electron Donor-Acceptor Blends: Insight into the Energy Losses in Organic Solar Cells. Adv. Funct. Mat. 2009, 19, 1939-1948.

5. Ran, N. A.; Kuik, M.; Love, J. A.; Proctor, C. M.; Nagao, I.; Bazan, G. C.; Thuc-Quyen, N., Understanding the Charge-Transfer State and Singlet Exciton Emission from Solution-Processed Small-Molecule Organic Solar Cells. Adv. Mat. 2014, 26, 7405-7412.

6. Vandewal, K.; Tvingstedt, K.; Gadisa, A.; Inganas, O.; Manca, J. V., Relating the OpenCircuit Voltage to Interface Molecular Properties of Donor:Acceptor Bulk Heterojunction Solar Cells. Phys. Rev. B 2010, 81. 